\title{
Computational analysis of fire dynamics inside a wind turbine
}

Rengel, B. ${ }^{1}$, Pastor, E. ${ }^{1}$, Hermida, D. ${ }^{2}$, Gómez, E. ${ }^{2}$, Molinelli, L. ${ }^{3}$, Planas, E. ${ }^{1}$

${ }^{1}$ Centre for Technological Risk Studies (CERTEC), Department of Chemical Engineering, Universitat Politècnica de Catalunya (EEBE), Eduard Maristany 10-14, 08019 Barcelona, Catalonia, Spain.

2 Gamesa, Ramírez de Arellano 37, 28043 Madrid, Spain.

${ }^{3}$ Eurisko Consulting, Patrimonio Mundial 7, 2-65, 28300 Aranjuez, Madrid, Spain.

Corresponding author: elsa.pastor@upc.edu 


\title{
Computational analysis of fire dynamics inside a wind turbine
}

\begin{abstract}
Wind turbines are generally considered cost-effective, reliable and sustainable energy sources. Fires are not common in wind turbines, but a significant number of fires occur every year due to the large number of turbines installed. Wind turbine fires are difficult to extinguish hence significant damage is expected. Due to the unmanned operation, the probability of a turbine being occupied during a fire is very low. However, operators can do several tasks every week, and hence be exposed to a certain risk. Moreover, there is a general lack of information about how a fire develops inside a wind turbine and the subsequent evolution of the tenability conditions during the time required for an eventual evacuation. Gamesa has been working on fire safety since 2013, using CFD fire modelling to provide insights on wind turbine fire development for the design of emergency procedures. The paper describes a fire hazard analysis performed in a Gamesa's 2.5 MW turbine. A CFD simulation is carried out to estimate the effects during the first minutes of a typical wind turbine fire in an electrical cabinet. Results show that average oxygen concentration at the nacelle remains above $19.5 \%$ during the first 10 minutes; temperature remains below $60^{\circ} \mathrm{C}$ for 12 minutes if measured at $1.5 \mathrm{~m}$; and visibility is on average assured at heights lower than $1.5 \mathrm{~m}$, with values above $5 \mathrm{~m}$ during the first 8 minutes in worse locations, implying no danger for personnel. The potential of this type of analysis to design safer wind turbines under performance-based approaches is clearly demonstrated.
\end{abstract}

KEYWORDS: modelling, CFD, compartment fires.

\section{INTRODUCTION}

Wind energy is one of the fastest new growing sources of electricity generation due to the multidimensional benefits associated: green power, sustainability and affordability [1]. Wind turbine operations start from the huge blades located on the rotor that transmit the captured energy to the gearbox, which enables the motion of the drive shaft that powers the electricity generator. Both, the gearbox and the generator, are located inside the nacelle, which represents the envelope that protects the wind turbines' mechanisms against weather agents and extreme environmental conditions. The 
nacelle is usually fitted with a natural ventilation system to prevent the turbine's failure by overheating.

Wind turbines are well accepted as alternative non-contaminant energy sources; however they can suffer severe incidents [2,3] (Fig. 1). Particularly, fires have already been identified as one of the most common causes of accidents in wind turbines during the last years [2] and indeed, a need to get more insights of fire risk in wind turbines has already been evidenced [2]. The fire's origin is related to diverse ignition sources (e.g. lighting strike, electrical equipment malfunction, hot surface ignition) and characterized by the large amount of highly flammable materials involved [2]. As can be observed in Fig.1, the number of wind turbine accidents has significantly grown since 2005 due to a continuous increase in the number of wind turbines installed during the last decades. In addition, the forecasted growth of the wind energy industry during the period 2017-2021 may lead to an increase on the number of accidents [4]. Even though technological improvements and the better understanding of the fire dynamics might have generally reduced the number of turbines fires, these latter still represent the $13 \%$ on average of the last ten years of the annual accidents recorded [3].

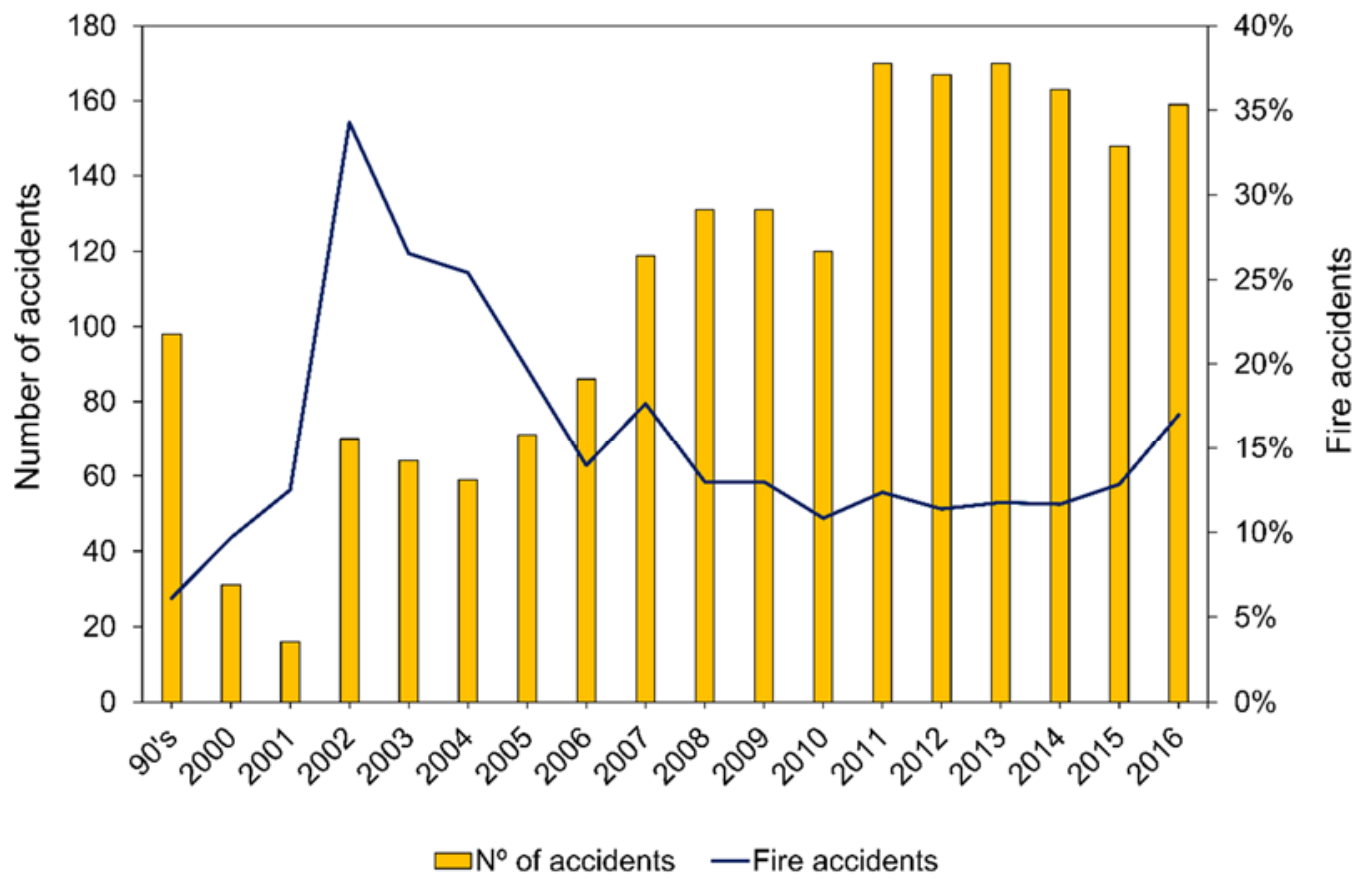

Fig. 1. Number of accidents and percentages of fires related to the total in wind turbines over the last years, worldwide $[2,3]$. 
In a wind turbine fire the total loss of the structure is expected as firefighters have difficulty reaching the remote wind farms locations and dealing with the nacelle's height [5]. Wind turbine fires lead to significant property damage and follow-up costs. In addition, they might be the cause of wildfires if ignited debris fall on the wildland [6]. Some fire protection systems (e.g. water mist) have been tested to protect wind turbines; however, their low suppression performances and their high application costs make them nowadays unattainable for wind turbine companies [7].

Historically, life safety was not considered an issue in wind turbines because they are unmanned. However, maintenance operators are exposed to a certain fire risk when performing preventive tasks inside the enclosure. When a fire arises in an occupied turbine, workers must reach a safe place before the egress routes become untenable. The duration of the practical environment for occupants mainly depends on the visible distance, the toxic products released by the fire, and the temperature [8]. Moreover, a low level of oxygen concentration as well as the smoke layer height may hinder the occupant's movements. There is a general lack of information about how a fire develops inside a wind turbine and the subsequent evolution of the tenability conditions during the time required for an eventual evacuation. However, there exist performance-based design (PBD) approaches that applied to this type of infrastructure could provide valuable insights to improve fire safety.

This paper presents, for the first time, a fire hazard analysis performed in a wind turbine that belongs to one of the leading companies of the wind industry. One scenario, estimated by the company as one of the most probable ones (i.e. fire originated at the nacelle with electrical cables as fuel load), was selected as a study case. The analysis was based on Computational Fluid Dynamics (CFD) modelling, by which the complexity of the system could be considered. Preliminary outcomes reveal that temperatures and smoke obscuration are the first factors affecting life's tenability.

\section{METHODOLOGY}

\subsection{Fire Scenario Definition}

We selected the most demanded wind turbine model, the G114, which has a rotor diameter of 114 meters and generates 2.5 MW. The turbine has a $163 \mathrm{~m}^{3}$ nacelle that integrates various ventilation elements (Fig. 2). 
a)

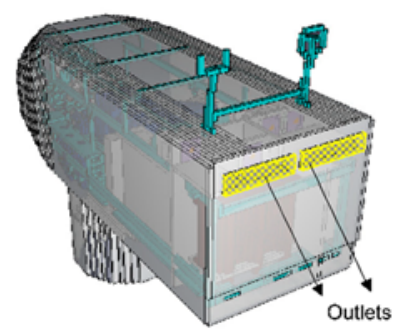

b)

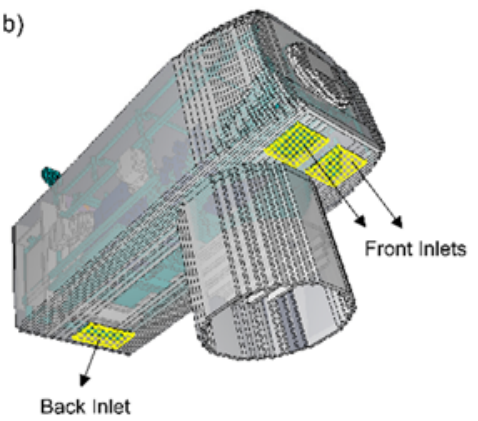

c)

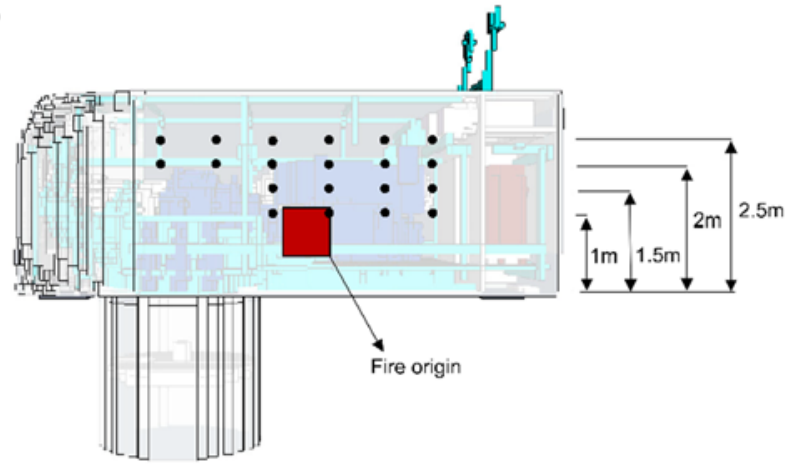

d)

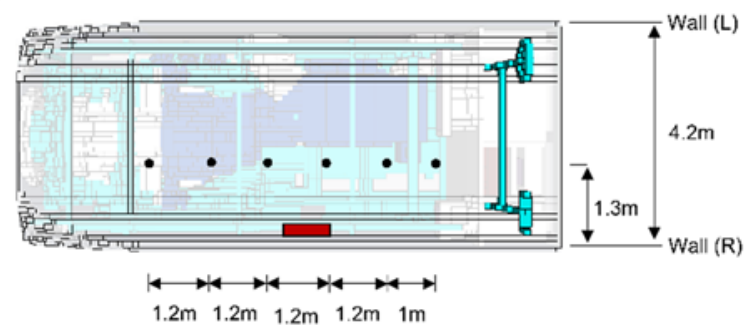

Fig. 2. Distribution of the a) outlet and b) inlet vents that compose the natural ventilation system; c) height and d) plan view with details on the location of measurement points (black dots) and fire origin (res surface). (L) left, (R) right.

We considered our fire scenario as an electrical cabinet burning in the nacelle $(0.5 \mathrm{~m}$ height over the stepped surface) as it is one of the most common fire sources according to the turbine's company historical database. True enough, other scenarios like lube oil fires could lead to more hazardous conditions. However, they were not taken into account in this study, as operating experience indicates that the primary first item ignited is electrical cabinets. The heat release rate (HRR) of the cabinet was established considering recommended values for fires in vertical cabinets with more than one cable bundle and closed doors [9]. We modelled a t-squared fire growth curve, with a rate of $8.9 \cdot 10^{-4} \mathrm{~kW} \cdot \mathrm{s}^{-2}$ during 12 minutes until achieving its maximum of $461 \mathrm{~kW}$, followed by a constant HRR during 8 minutes before the decay phase.

Thermal properties of wind turbine components were defined (Table 1) to account for heat losses and their influence on fire behaviour. Even PVC and FRP materials might have been ignited because of high radiant fluxes or elevated temperatures, the electrical cabinet was assumed as the only burning material contributing to the fire development, which was the targeted period under 
study. Ventilation ducts were characterized by a loss coefficient of 0.3 according to the inlet shape [10].

Table 1. Thermal properties of wind turbine compounds.

\begin{tabular}{lccc}
\hline \multicolumn{1}{c}{ Parameter } & Steel & $\begin{array}{c}\text { Polyvinylchloride } \\
\text { (PVC) }\end{array}$ & $\begin{array}{c}\text { Fiberglass reinforced } \\
\text { polyester (FRP) }\end{array}$ \\
\hline Reference & {$[11]$} & {$[12]$} & {$[13]$} \\
Location & Structure & Ventilation ducts & Nacelle \\
Specific heat $\left(\mathrm{kJ} \cdot \mathrm{kg}^{-1} \cdot \mathrm{K}^{-1}\right)$ & 0.46 & 1.2 & 1.673 \\
Conductivity $\left(\mathrm{W} \cdot \mathrm{m}^{-1} \cdot \mathrm{K}^{-1}\right)$ & 45.8 & 0.134 & 0.295 \\
Density $\left(\mathrm{kg} \cdot \mathrm{m}^{-3}\right)$ & 7,850 & 1,380 & 1,795 \\
Emissivity & 0.95 & 0.9 & 0.92 \\
\hline
\end{tabular}

\subsection{Computational Fluid Dynamics Settings}

Fire Dynamics Simulator 6.4.0 (FDS6) developed by the NIST (National Institute of Standards and Technology) was used to evaluate the proposed fire scenario [14]. The simulation was run for 15 minutes considering the Large Eddy Simulation (LES) turbulence model. The volume modelled was divided in ten different meshes with a cell size of $0.05 \mathrm{~m}^{3}$ according to the characteristic fire diameter and cell size ratio based on the total heat release rate [15]. The fire was modelled as a prescribed heat release rate using the FDS single-step simple chemistry model while the gas phase combustion was described by employing the single chemistry mixing-controlled approach. This combustion method assumes an infinitely fast reaction of fuel and oxygen and only allows one single gaseous fuel resulting from the combustion process. As the cabinet cables are mainly made of thermoplastic compounds, which can be either unqualified or IEEE-383 qualified [16], polyethylene (PE) was selected as the main fuel of the reaction of combustion (Table 2).

Table 2. Reaction of combustion for polyethylene [17]. 


\begin{tabular}{lc}
\hline \multicolumn{1}{c}{ Parameter } & Polyethylene \\
\hline Formula & $\mathrm{C}_{2} \mathrm{H}_{4}$ \\
$\mathrm{CO}$ yield $\left(\mathrm{kg} \cdot \mathrm{kg}^{-1}\right)$ & 0.024 \\
Soot yield $\left(\mathrm{kg} \cdot \mathrm{kg}^{-1}\right)$ & 0.060 \\
Heat of combustion $\left(\mathrm{kJ} \cdot \mathrm{kg}^{-1}\right)$ & 38,400 \\
\hline
\end{tabular}

Temperature and smoke obscuration were measured in several points located in the nacelle at different heights $(1,1.5,2$ and $2.5 \mathrm{~m})$ over the stepped surface distributed along six columns separated by $1.2 \mathrm{~m}$ (20 measurement points in total, see Fig. 2). Additionally, we measured the position of the interface between the hot-upper and the cooler-lower layer (i.e. smoke layer height) and the average oxygen concentration in the nacelle, both measurements at each mesh (10 measurements available at each instant for both variables). Finally, we quantified the maximum temperatures and the maximum heat radiant fluxes that the walls and ceiling of the nacelle received.

\section{RESULTS}

Concerning the evolution of the smoke layer height, we observe a rapid reduction from $3.7 \mathrm{~m}$ to 2.5 $\mathrm{m}$ height during the first 4 minutes (Fig. 3a). After that, the smoke interface remains approximately $2 \mathrm{~m}$ above the stepped surface, evolving uniformly all over the nacelle (maximum and minimum height values differences are less than $0.2 \mathrm{~m}$ ). The average oxygen concentration starts decreasing 5 minutes after the fire begins. The minimum concentration found next to the fire origin, was 0.18 $\mathrm{mol} / \mathrm{mol}$ at the end of the simulation. 
a)

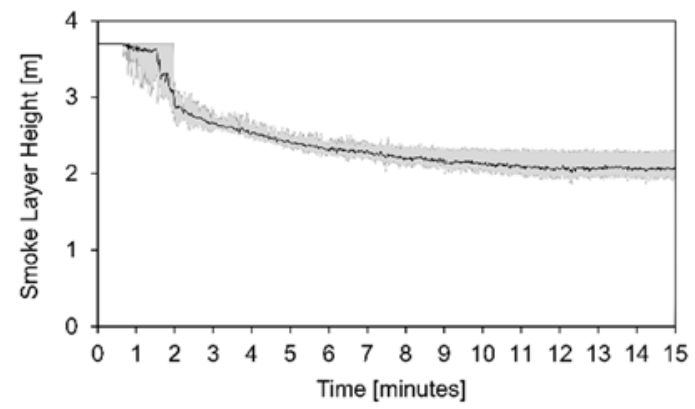

b)

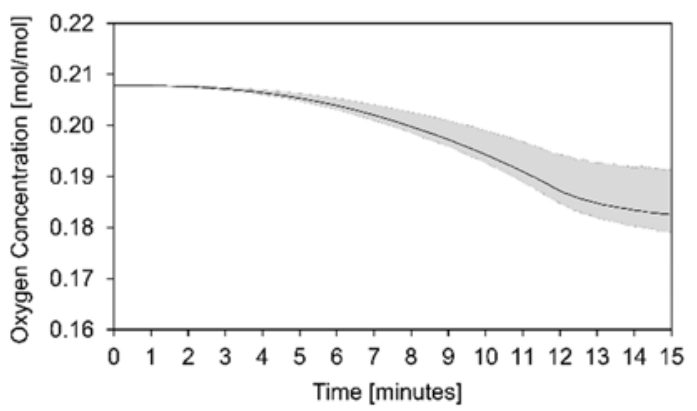

Fig. 3. a) Evolution of the smoke layer height and b) the oxygen concentration inside the nacelle. Black lines represent average values calculated throughout the nacelle (divided in 10 meshes).

Grey shadowed areas comprise the region between maximum and minimum values.

Regarding temperatures, we notice that, as expected, the higher the measurement points were located, the higher were the values found (Fig. 4a). At a height of $1 \mathrm{~m}$ temperature variations were negligible while at $1.5 \mathrm{~m}$ the temperature may exceed $50{ }^{\circ} \mathrm{C}$ after 11 minutes. At $2 \mathrm{~m}$ and $2.5 \mathrm{~m}$ above the nacelle ground mean temperatures reached values around $100^{\circ} \mathrm{C}$ and $150^{\circ} \mathrm{C}$ after 12 minutes, respectively. Excepting measurements close to the fire origin at $2.5 \mathrm{~m}$ height (that registered the highest values), temperatures were rather homogeneous all over the nacelle for each height.

The visibility diminished when the measurement height increased (Fig. 4b). At a height of $2.5 \mathrm{~m}$, the smoke obscuration dropped below $1.5 \mathrm{~m} 6$ minutes after the fire ignited. Furthermore, at $1.5 \mathrm{~m}$ or less above the stepped surface, the visibility mainly depended on the measurement location. The maximum values were registered near the fire origin while the minimum ones were found near the outlet points. In this later case, minimum visibility decreased below $5 \mathrm{~m}$ at $1 \mathrm{~m}$ height, 8 minutes after the fire started.

These results, together with the already examined smoke layer position (average smoke layer height above $2 \mathrm{~m}$ in Fig. 3), point that a fully stratified two-layer environment is not present in this case (i.e. with the soot yield fixed at 0.06 , and temperatures around $50^{\circ} \mathrm{C}$ at $1.5 \mathrm{~m}$ height during the last 4 minutes of simulation, the minimum visibility is close to zero). 
a) Temperature
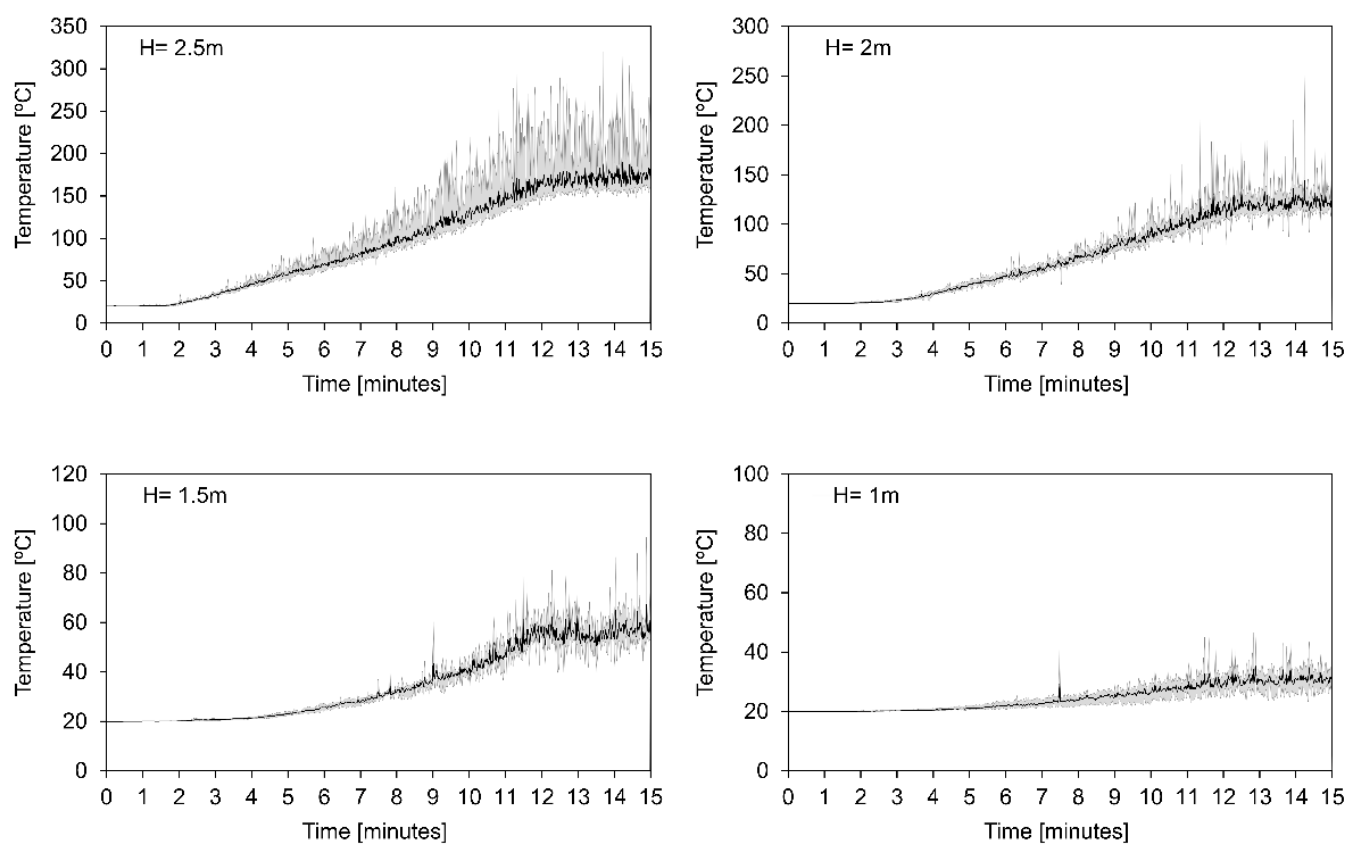

b) Smoke Obscuration
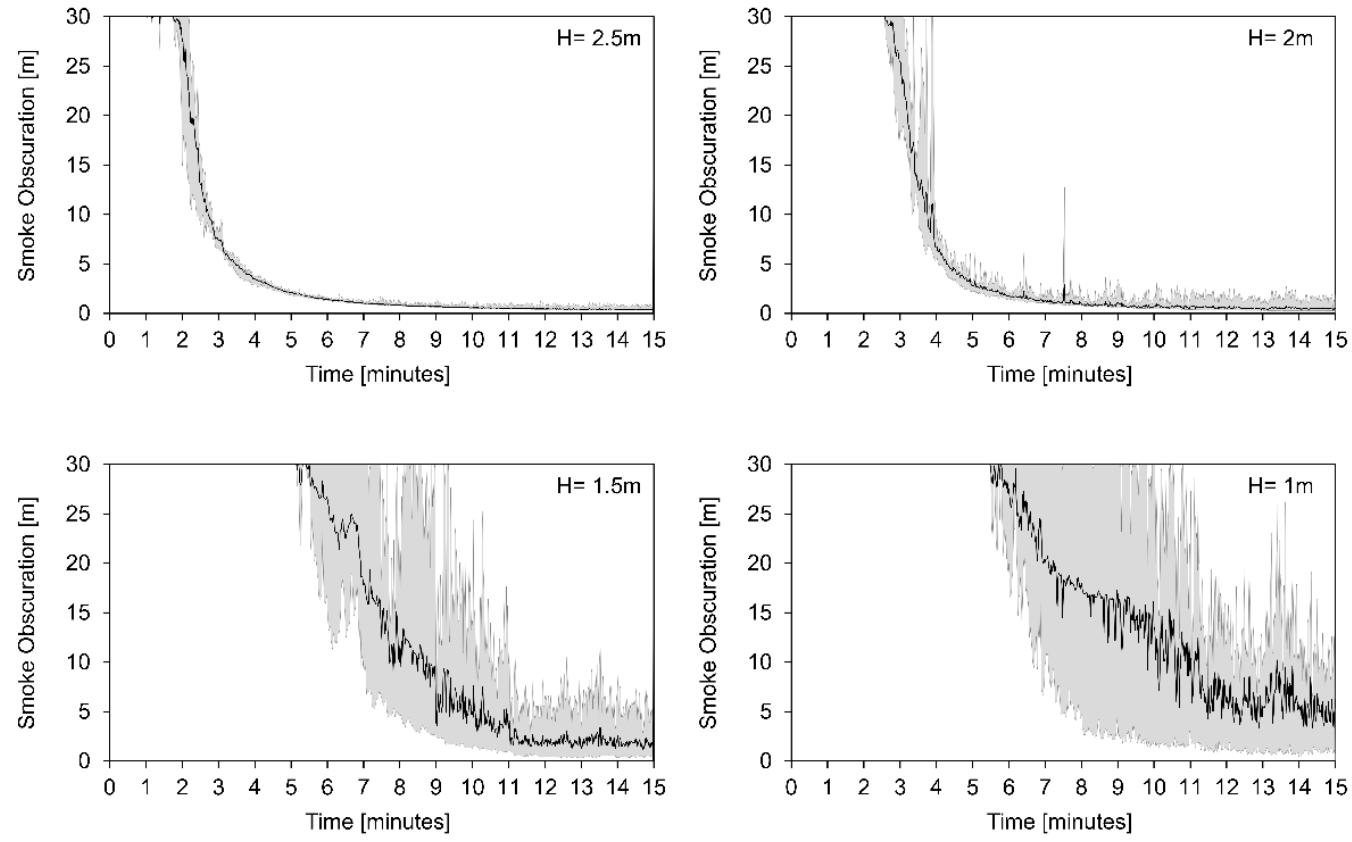
Fig. 4. a) Temperature and b) smoke obscuration evolution inside the nacelle, at four different heights $(\mathrm{H})$. Smoke obscuration is expressed as the visible distance $(\mathrm{m})$ for occupants inside the turbine. Black lines represent average values, calculated considering 6 (for $2.5 \mathrm{~m}$ and $2 \mathrm{~m}$ height) and 4 (for $1 \mathrm{~m}$ and $1.5 \mathrm{~m}$ height) different locations. Grey shadowed areas comprise the region between maximum and minimum values.

The maximum values of the wall temperatures and the maximum thermal radiant flux experienced by the ceiling and the walls are shown in Fig. 5. During the first ten minutes, the radiated flux can be neglected in the analysed surfaces. Then, the ceiling suffers an exponential growth of the thermal flux received that may achieve maximum averaged values around $14 \mathrm{~kW} / \mathrm{m}^{2}$. On the other hand, the temperatures in the walls exceed $50^{\circ} \mathrm{C}$ approximately 10 minutes (right wall) and 12 minutes (left wall) after ignition, achieving maximum values between 130 and $80^{\circ} \mathrm{C}$, respectively. The maximum ceiling temperature reaches $110^{\circ} \mathrm{C}$ after 10 minutes and then it rapidly rises reaching a maximum of $280^{\circ} \mathrm{C}$ at the end of the simulation.
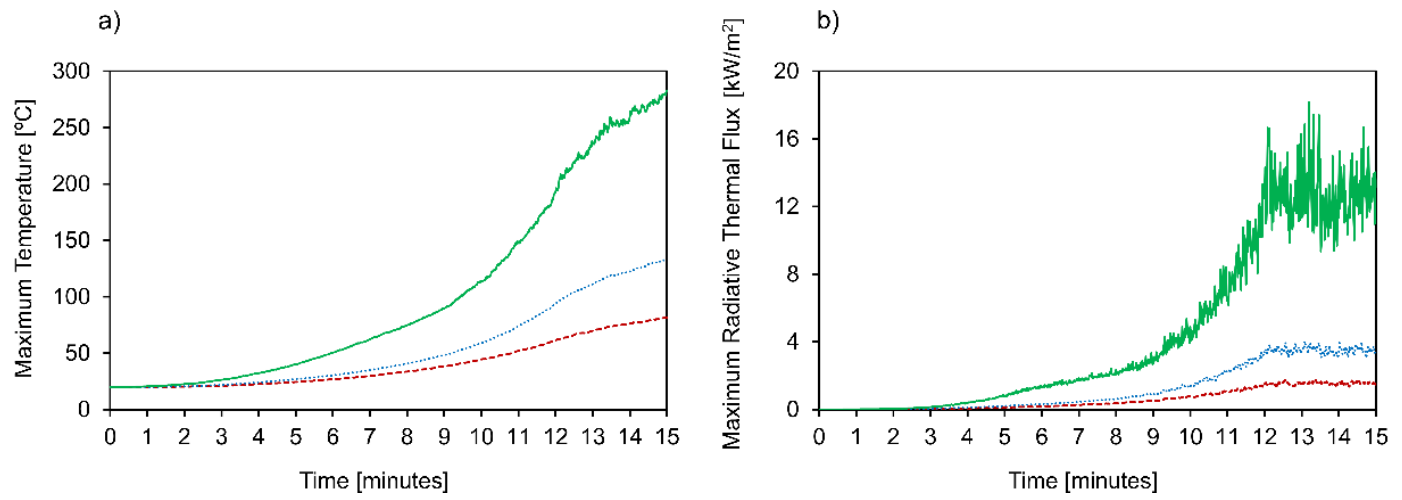

Fig. 5. a) Ceiling maximum temperatures evolution walls (L, left and R, right) and b) maximum radiative thermal flux evolution.

\section{CONCLUDING REMARKS}

This paper shows a fire hazard analysis of a wind turbine fire scenario, with origin in an electrical cabinet, based on CFD modelling performed to get insights on fire development and its subsequent effects during the first minutes of the event.

The results show that the natural ventilation of the nacelle helps to maintain the concentration of the oxygen above the tenability limits during the period of study. The average concentration remains 
at values above $19.5 \%$ during the first 10 minutes, implying no danger for personnel [18]. Regarding temperatures and visibility, we remark that the largest differences among data occur at heights between 1.5 and $2 \mathrm{~m}$. This coincides with the estimated smoke layer height $(\mathrm{H}>2 \mathrm{~m})$. In any case, egress is possible if personnel keep low where the air is clearer. Temperature remains below $60^{\circ} \mathrm{C}$ for 7 minutes if measured above $2 \mathrm{~m}$ and even longer (12 minutes) if measured at 1.5 $\mathrm{m}$. Visibility is in average assured at heights lower than $1.5 \mathrm{~m}$, with values above $5 \mathrm{~m}$ during the first 8 minutes in worse locations. Under these conditions, tenability is guaranteed $[19,20]$. The ceiling of the nacelle could undergo thermal effects, particularly an averaged maximum radiative heat flux of $14 \mathrm{~kW} / \mathrm{m}^{2}$ and temperatures higher than $250^{\circ} \mathrm{C}$. An in-depth knowledge of the nacelle compounds might determine its possible contribution to the fire development.

The results presented in this paper show the great potential that this type of analysis has to undertake performance-based fire safety design (PBD) in wind turbines. In a PBD complete project, however, a more comprehensive study is needed, which could include, among others, a sensitivity analysis related to cell dimensions, the consideration of other frequent fire scenarios, other boundary conditions considering wind effects, uncertainty quantification related to the most critical FDS inputs, etc.

Data collected in this paper together with data from other frequent fire scenarios and wind turbine models are currently being used by Gamesa to establish the emergency protocols using an ASET (Available Safe Egress Time)/ RSET (Required Safe Egress Time) approach. Based on the identification of the most challenging ignition points and their consequences, Gamesa is conducting further studies and tests, and improving their designs to deliver safer wind turbines.

\section{ACKNOWLEDGEMENTS}

Spanish Ministry of Economy and Competitiveness (project CTM2014-57448-R, co-financed with FEDER funds), Spanish Ministry of Education, Culture and Sport (FPI Programme) and Autonomous Government of Catalonia (project no. 2014-SGR-413). 


\section{REFERENCES}

[1] Lu MS, Chang CL, Lee WJ, Wang L (2008) Combining the wind power generation system with energy storage equipments. Industry Applicatons Society Annual Meeting 45:6. doi: 10.1109/08IAS.2008.139

[2] Uadiale S, Urbán É, Carvel R, Lange D, Rein G (2014) Overview of Problems and Solutions in Fire Protection Engineering of Wind Turbines. Fire Safety Science 11:983995. doi:10.3801/IAFSS.FSS.11-983

[3] Caithness Windfarm Information Forum (2017) Summary of Wind Turbine Accident data. http://www.caithnesswindfarms.co.uk/fullaccidents.pdf. Accessed 30 February 2017

[4] Global Wind Energy Council (GWEC) (2016) Global Wind Report, Annual market update 2016

[5] VdS VERLAG (2008) Wind Turbines Fire Protection Guidelines. The International Association of Engineers Insurers. http://en.dbi-

net.dk/files/CFPA/Guidelines/CFPA_E_Guideline_No_22_2012_F.pdf. Accessed 30 June 2016

[6] Whittlesey RW (2012) Wind Turbines And Wildfires: Is Your Wind Farm in Danger? North American Wind Power.

http://nawindpower.com/online/issues/NAW1408/FEAT_04_Qind-Turbines-AndWildfires-Is-Your-Wind-Farm-In-Danger.html. Accessed August 2014

[7] Chiu CW, Li YH (2015) Full-scale experimental and numerical analysis of water mist system for sheltered fire sources in wind generator compartment. Process Safety and Environmental Protection 98:40-49, http://dx.doi.org/10.1016/j.psep.2015.05.011

[8] Klote JH (2012) Human Exposure to Smoke. In: Klote KJ (ed.) Handbook of Smoke Control Engineering, edn. ASHRAE, Atlanta, pp 171-188

[9] Lindeman A, Salley MH (2016) Refining And Characterizing Heat Release Rates From Electrical Enclosures During Fire (RACHELLE-FIRE), NUREG-2178, U.S. Nuclear Regulatory Commission and Electric Power Research Institute, Washington.

[10] Butcher K.J. (2007) CIBSE Guide C: Reference data, CIBSE, London 
[11] Drysdale D (1985) An Introduction to Fire Dynamics, John Wiley and Sons, Chichester

[12] Hamins A, Maranghides R, Johnsson M, Donnelly J, Mulholland G, Anleitner RL (2006) Report of Experimental Results for International Fire Model Benchmarking and Validation Exercise \#3, NUREG/CR-6905, National Institute of Standards and Technology, Gaithersburg MD

[13] Chiam BH (2005) Numerical Simulation of a Metro Train Fire, Fire Engineering Research Report 05/1, Christechurch

[14] McGrattan K, Hostikka S, McDermott R, Floyd J, Weinschenk C, Overholt K (2015) Fire Dynamics Simulator User's Guide, National Institute of Standards and Technology, NIST Special Publication 1019 Sixth Edition, Gaithersburg MD

[15] Sally MH, Lindeman A (2016) Verification and Validation of Selected Fire Models for Nuclear Power Plant Applications, NUREG-1824, Electric Power Research Institute and US Nuclear Regulatory Commission, Washington DC

[16] Chavez JM (1987) An Experimental Investigation of Internally Ignited Fires in Nuclear Power Plant Control Cabinets: Part 1: Cabinet Effects Tests, NUREG/CR-4527-1, U.S. Nuclear Regulatory Commission, Washington DC

[17] Khan MM, Tewarson A, Chaos M (2016) Combustion Characteristics of Materials and Generation of Fire Products. In: Hurley MJ (ed) SFPE Handbook of Fire Protection Engineering, $5^{\text {th }}$ edn. Springer, New York, pp 1143-1232

[18] Casal J (2008) Evaluation of the effects and consequences of major accidents in industrial plants, Industrial Safety Series, ElSevier, UK

[19] Purser D, McAllister JL (2008) Assessment of hazards to occupants from smoke, toxic gases and heat. In: Hurley MJ (ed) SFPE Handbook of Fire Protection Engineering, $5^{\text {th }}$ edn. Springer, New York, pp 2308-2428

[20] Jin T (1981) Studies of emotional instability in smoke from fire. Journal of fire and flammability $12(2): 130-142$ 